\title{
Religious Wars in the NDE Movement
}

To the Editor:

I heartily commend the Editor and the editorial board of the Journal for their airing of the controversy surrounding the NDE "religious wars" in the Summer 2000 issue (Ring, 2000; Sabom, 2000). This is a courageous stance, especially given the subject matter, but it is one of infinite value to everyone interested in near-death experiences. As a scholar serving on the editorial boards of several other juried journals, I was overjoyed to see what is all too rare in most academic periodicals: creating a public forum where the internecine conflicts among leading thinkers are accessible to the larger community.

Clashes among researchers take place in every field. All too often, however, they remain private, creating an elite cognoscenti who "really know" what is going on, leaving the rest of the community far behind. Thus the most interesting conversations either happen between privileged individuals or not at all. The result is a spurious image of unification (the proverbial elephant in the living room), apparently uncritical acceptance of conflicting ideas, an uninformed public, and rather dull journals. To avoid critique and debate is to deprive the larger community of the greatest benefits of fine minds: their contribution to discernment into the heart of the issues.

As someone who deplores hidden religious agendas in any transpersonal field (Wade, 1999), I am particularly glad to see the subject out in the open, especially when it is debated by such esteemed scholars as Kenneth Ring and Michael Sabom in a respectful and professional manner. Although I found myself more in sympathy with Ring's views and generally concur with his position, Sabom's riposte was very effective. He made some excellent points, and cut away some of the thrust of Ring's arguments, though Sabom appeared to be somewhat selective in 
what he addressed. If anything, I was sorry not to see a rejoinder from Ring to Sabom's rebuttal, as is usual in such instances. I know from private conversations that he could have marshaled a staunch defense to at least some of Sabom's critique, but I understand Ring declined the opportunity to do so in advance. The larger NDE community is the loser for Ring's decision, but I hope others will further and deepen the conversation Ring and Sabom initiated.

I would also like to take this opportunity to underscore what I consider one of the most significant ideas emerging from this debate, which may be somewhat lost in the religious discussion: Ring's retraction of his earlier position that somehow a critical mass of altered-state experiences such as NDEs heralded the coming of a golden age of higher planetary consciousness. In our earliest professional correspondence, Ring and I debated this issue, and I urged him to make his new thinking public. Knowing it would be an unpopular stance in the NDE community, he was understandably reluctant. But another impediment was not having an appropriate forum in which to air such a change of mind. Years passed. Had this opportunity not arisen in the Journal of NearDeath Studies, the public would have been deprived of a significant new direction taken by one of its most prominent and influential thinkers, perhaps forever.

\section{References}

Ring, K. (2000). Religious wars in the NDE movement: Some personal reflections on Michael Sabom's Light \& death. Journal of Near-Death Studies, 18, 215-244.

Sabom, M. (2000). Response to Kenneth Ring's "Religious wars in the NDE movement: Some personal reflections on Michael Sabom's Light \& death." Journal of Near-Death Studies, 18, 245-271.

Wade, J. (1999). [Review of The eternal journey: How near-death experiences illuminate our earthly lives]. Journal of Near-Death Studies, 18, 51-57.

Jenny Wade, Ph.D.

Interim President, The Graduate Institute

235 Uplands Circle

Corte Madera, CA 94925

e-mail: JwadePhD@yahoo.com 